УДК 665.11:502.174.1:628.03-027.236

DOI

\title{
РОЗРОБКА ЕНЕРГОЕФЕКТИВНОЇ ТЕХНОЛОГІї УТИЛІЗАЦІЇ ВІДХОДІВ ОЛІЙНО-ЖИРОВОЇ ГАЛУЗІ
}

Скляр Вікторія Юріївна, аспірант, Крусір Галина Всеволодівна, д.т.н., проф., Коваленко Ірина Вікторівна, к.т.н., доц., Кузнсцова Ірина Олександрівна, к.т.н., доц.,

Шпирко Тетяна Василівна, к.т.н., доц.

Одеська національна академія харчових технологій, м. Одеса

\begin{abstract}
Анотація. Сучасні технологї виробництва олійно-жирової продукції передбачають фільтрацію з використанням вибільних глин. Цей сорбент використовується одноразово, тому він накопичується у великих кількостях на комбінатах як побічний продукт. Даний матеріал відносять до IV класу небезпеки за його здатність до самозаймання. Тому питання щзодо вирімення проблеми його утилізації є актуальним. Біотехнологічна переробка иุих відходів в корисні продукти є найбільш дочільною та ефективною з точки зору енергоефективних, екологічних та економічних вимог.

В статті розглянуто стан ринку України, класифікація утворення відходів олійно-жирової галузі, напрями маловідходних та безвідходних технологій. Показано біотехнологічний потенціал мікробних ліпаз, перспективність та доцільність застосування біотехнологічного методу утилізації жирової фракцї відходів з використанням ферментних препаратів. Розглянуто умови ферментолізу відходу виробництва саломасу та маргаринової продукиї ліпазою Rhizория јаропісиs, зокрема ї̈ термостабільність.

Одержані результати дослідження свідчать про перспективність гідролізу відходів ліпазою Rhizория. Встановлено, щуо вміст вільних жирних кислот в гідролізаті досягає рівня насичення через 72 год ферментативного гідролізу, а конщентрація триглічеридів зменшується до мінімального значення. Термостабільність ліпази Rhizopus јаропісиs досягає максимального значення при $40^{\circ} \mathrm{C}$.
\end{abstract}

Ключові слова: олієвмісні відходи, жирова фракція, фермент, ліполіз, енергоефективність, безвідходні та маловідходні технології.

\section{DEVELOPMENT OF ENERGY-EFFICIENT TECHNOLOGY FOR UTILIZATION OF WASTE OIL AND FAT INDUSTRY}

V. Skliar, Postgraduate, G. Krusir, Doctor of Technical Science, Professor, I. Kovalenko, Ph.D in Technical Science, Associate Professor, I. Kuznecova, Ph.D in Technical Science, Associate Professor, T. Shpyrko, Ph.D in Technical Science, Associate Professor Odessa National Academy of Food Technologies, Odessa

\begin{abstract}
Modern technologies of production of oilseed fat products involve filtration using viable clays. Depending on the technology, 12-15 kg of bleaching clay are used per 1 ton of vegetable oil. Every year, about 80 tons of waste clay accumulates at the oil refinery with a capacity of 100 tons / day of oil. Depending on the technological process, the oil content in the bleaching clays after their mining can reach 65\%. This sorbent is used once, so it is accumulated in large quantities at combines as a by-product. This material is classified as hazard class IV for its self-ignition ability. Therefore, the issue of solving the problem of its utilization is relevant. And biotechnological processing of these wastes into useful products is the most expedient and effective in terms of energy-efficient, ecological and economic requirements.

The article deals with the state of the Ukrainian market, the classification of waste of the oil and fat industry, the directions of low-waste and non-waste technologies. The biotechnological potential of microbial lipases is shown, perspective and expediency of application of biotechnological method of utilization of fat fraction of waste using enzyme preparations. The conditions of fermentolysis of the waste of hydrogenated fat and margarine production of Rhizopus japonicus lipase, in particular its thermal stability, are considered.

The obtained results of the study indicate the prospect of hydrolysis with Rhizopus lipase. It has been established that the content of free fatty acids in the hydrolyzate reaches the level of saturation after 72 hours of enzymatic hydrolysis, and the concentration of triglycerides is reduced to a minimum value. The thermal stability of lipase Rhizopus japonicus reaches a maximum at $40^{\circ} \mathrm{C}$. The results of research should be used to improve the technology of processing waste oil and fat industry food and processing industries.
\end{abstract}

Key words: oily waste, fat fraction, enzyme, lipolysis, energy efficiency, waste-free and low-waste technologies. 
Вступ. Харчова та переробна промисловість, як і багато інших галузей народного господарства, $є$ джерелом негативного впливу на навколишнє середовище.

Виробництво олійно-жирової продукції в Україні є вагомою галуззю агропромислового комплексу. Основним видом олій на українському ринку залишається соняшникова - 70\% від всього обороту ринку, на другому місці - пальмова олія - 20\% загального об’єму продажу, а інші види - $10 \%$ ринку. Виробництво рослинних олій має місце на олійно-жирових комбінатах, там же виробляються маргарин, майонез, гліцерин, мило та миючі засоби на жировій основі, оліфи та інш. продукти, при виробництві яких використовують рослинні олії в якості сировини (рис.1).

\begin{tabular}{|c|c|}
\hline $\begin{array}{c}\text { Олія соняшникова нерафінована } \\
\text { ( } \text { урахування олійниць) }\end{array}$ & $\begin{array}{l}\text { • Зменшення до } 3362 \text { тис. тонн пр оти } 3642 \text { тис. } \\
\text { тонн або } 92,3 \%\end{array}$ \\
\hline $\begin{array}{c}\text { Олія соняшникова нерафінована } \\
\text { (без олійниць) }\end{array}$ & $\begin{array}{l}\text { • Зменшення до } 3089 \text { тис. тонн пр оти } 3436 \text { тис. } \\
\text { тонн або } 90 \%\end{array}$ \\
\hline Олія соняшникова рафінована & $\begin{array}{l}\text { - Зростання до } 397,5 \text { тис. тонн пр оти } 393,1 \text { тис } \\
\text { тонн або } 101,1 \%\end{array}$ \\
\hline Олія соєва & $\begin{array}{l}\text { • Зростання до } 118,7 \text { тис. тонн пр оти 96,4 тис } \\
\text { тонн або } 123,1 \%\end{array}$ \\
\hline Олія ріпакова & $\begin{array}{l}\text { • Зростання до 46,9 тис. тонн пр оти } 27 \text { тис тонн } \\
\text { або } 173,7 \%\end{array}$ \\
\hline $\begin{array}{c}\text { Маргаринова продукціята жири спец. } \\
\text { призначення }\end{array}$ & $\begin{array}{l}\text { •'Зростання до } 149,7 \text { пис. тонн пр оти 130,6 тис. } \\
\text { тонн або } 114,6 \%\end{array}$ \\
\hline Майонез та соуси & $\begin{array}{l}\text { - Зростання до } 80,81 \text { тис тонн пр оти } 76,8 \text { тис. } \\
\text { тонн або } 105,2 \%\end{array}$ \\
\hline
\end{tabular}

Рис. 1- Виробництво олійно-жирової продукції в Україні у вересні-березні 2017/18 МР

Щорічно в Україні в процесі виробництва олійно-жирової продукції на різних стадіях утворюються численні жирові відходи і побічні продукти. Обсяги утворення цих відходів в цілому по Україні за оцінками фахівців складають 30 млн. тонн, а середній рівень їх промислової переробки ледь перевищує 30 \% від утвореної маси [1].

Аналіз проблематики та останніх досліджень. В олійно-жировій промисловості при переробці насіння олійних культур і виробництві олії рослинної, маргаринової продукції і майонезу утворюються наступні побічні продукти і відходи: соняшникове лушпиння, макуха, шрот, фосфатні концентрати, соапсточні жири, погони дезодорації, відпрацьована вибільна глина (сорбент) і каталізатор, содові розчини, гудрон, стічні води.

Вимоги сучасного ринку диктують необхідність створення і впровадження у виробництво технологій 3 низькою енерго-, ресурсо- і капіталоємністю, що дозволяє випускати якісну і конкурентоспроможну продукцію.

У олійно-жировій промисловості найбільш енергоефективними, екологічними та перспективними $\epsilon$ наступні напрями маловідходних та безвідходних технологій [2]:

- розробка і впровадження нових процесів і устаткування (котлоагрегатів), що забезпечують виробництво технологічної пари шляхом спалювання лушпиння;

технологія рафінації олій за схемою: парова гідратація - нейтралізація в мильно-лужному середовищі - фільтрація з метою більш повного вилучення та раціонального використання фосфатидів та отримання 3 них товарної продукції;

- впровадження комплексу заходів для скорочення водоспоживання, очищення бензожирових стоків iз застосуванням прогресивних методів, зокрема мембранних;

- біотехнологічна переробка вторинних сировинних ресурсів олійно-жирової галузі в корисні продукти.

За джерелами утворення вторинні сировинні ресурси олійно-жирової галузі і відходи можна класифікувати:

на стадії пресування і форпресування - екстракції олійного насіння - вторинною сировиною $є$ макуха і шрот; лушпиння є відходом;

- на стадії гідратації олії як ВСР отримують фосфатидні концентрати;

- на стадії нейтралізації або лужного рафінування вторинною сировиною є соапсточні жири і відпрацьовані лужні розчини;

- в процесі вибілювання олії як відходи отримують жир, що міститься у використаній вибільній глині; 
- при дезодорації рослинної олії і жирів утворюється вторинна сировина (побічний продукт) - погони дезодорації;

при гідрогенізації олій і жирів (отримання саломаса харчового для маргарину і технічного для миловаріння) відходом є жир у відпрацьованому каталізаторі;

при фільтрації масел - як відходи, отримують відпрацьований порошок.

Процес гідрогенізації рослинних олій в олійно-жировому виробництві супроводжується утворенням великотонажних відходів, основними з яких є відпрацьована глина (сорбент) зі стадії додаткового відбілювання та відпрацьований каталізатор. Технологія очищення рослинних олій і гідрогенізованих жирів (саломасів) включає такі етапи як вибілювання та фільтрацію. В якості сорбентів використовуються бентонітова глина та діатомітові фільтруванні порошки. Кількість сорбенту залежить від вмісту в олії барвників, потрібною ступеню освітлення і коливається від 0,2 до 4\%. В залежності від технології на 1 т рослинної олії використовується 12-15 кг вибільної глини. Щорічно на олійно-переробному заводі продуктивністю 100 т/добу олії накопичується близько 80 т відпрацьованої глини [1,2]. В залежності від технологічного процесу вміст олії у вибільних глинах після їх відпрацювання може досягати $65 \%$.

Олії, які містяться у відходах виробництва, $є$ низькокалорійним паливом. Утилізації таких відходів супроводжується активним перебігом окиснення. У спекотний період року вони можуть самозайматись, самоспалахувати, тліти, виділяти неприємний запах згірклого окисненого жиру. Найбільш простим способом вирішення проблеми утилізації відпрацьованих вибільних глин у технології очищення рослинних олій і гідрогенізованих жирів $\epsilon$ технологія, що передбачає їх вивезення на звалища твердих відходів. Але транспортування та поховання цих залишків пов'язані із додатковими витратами і завдають шкоди довкіллю. Викидати відпрацьовані вибільні глини не дозволяється.

Відпрацьовані глини можуть бути використані як мінеральні добавки у комбікормах, але використання їх у цьому напрямку недоцільно, оскільки економічні затрати значно перевищують позитивний ефект відгодівлі. Існує метод утилізації відпрацьованих олієвмісних відходів шляхом виготовлення на їх основі побутових паст для чищення, миючих засобів. Пропонується використання вибільних глини як альтернативних джерел сировини для виробництва біодизельного палива. Відома низка технологій, що заснована на знежирюванні відходів, а масу вибільної глини або фільтрувального порошку можна використовувати у якості сировинних матеріалів при виробництві асфальту, бетону, цегли та інших будівельних матеріалів. Деякими авторами запропоновано лінію виробництва біопрепаратів на основі техногенних відходів олійно-жирової промисловості, технологію контрольованого спалювання з використанням отриманого тепла для технологічних потреб знежирення гарячою водою або кип'ятінням з розчином хлориду натрію чи карбонату натрію 3 одержання технічного жиру і сухого залишку як замінника землі чи піску для звалищ. Існують методи знежирення відпрацьованих вибільних глин за допомогою надкритичного діоксиду вуглецю або летких розчинників (гексан), а також під тиском (0,3-3 МПа) у комбінації з водою і гідроксидом натрію [3-6].

Найбільш ресурсо-, енергоефективним та екологічним методом є біотехнологічна утилізація відпрацьованої глини (сорбенту) шляхом ферментативного гідролізу [7] .

Мета роботи - дослідження умов продуктивного ферментолізу ліпазою мікробного походження Rhizopus japonicus жирової фракції відходів, що утворюються при гідруванні рослинних масел.

Завдання роботи - провести характеристику ферментолізу субстратів, провести гідроліз саломасу, визначити термостабільність ліпази Rhizopus japonicus по відношенню до саломасу.

Біотехнологічні процеси переробки базуються на природних процесах, які практично не мають побічних ефектів, є продуктивними, безпечними, ресурсо- та енерго- ефективними для біоти та компонентів навколишнього середовища.

Мікробні ліпази складають важливу групу біотехнологічно цінних ферментів [8]. Причинами величезного біотехнологічного потенціалу мікробних ліпаз є факти того, що вони:

- можуть використовуватись як заміна агресивним хімічним сполукам, що зменшує екологічну небезпеку, дозволяє запобігти забрудненню, виключає використання корозійно-стійкого обладнання;

- можуть бути використані для обробки та утилізації відходів, до складу яких входять шкідливі сполуки;

високоспецифічні, тому виключаються утворення побічних небажаних продуктів та необхідність проведення складних технологічних процесів;

- функціонують краще при низьких температурах;

- можлива модифікація шляхом іммобілізації, що сприяє багатократному їх використанню;

- здатні розкладатися природним шляхом за допомогою деструкторів, тому всі хімічні компоненти ферментів включені до природного екологічного циклу [9].

Матеріали та методи досліджень. Об'єктами дослідження були 7 ліполітичних ферментних препаратів, характеристики яких наведені в табл. 1 та саломас (ПрАТ «Вінницький ОЖК»), процес одержання якого наведено на рис. 2.

Таблиия 1

Наукові праці, Том 83, випуск 1

Scientific Works, Volume 83, Issue 1 
Одеська національна академія харчових технологій ІННОВАЦІЙНІ ЕНЕРГОТЕХНОЛОГІЇ ХАРЧОВИХ ВИРОБНИЦТВ

\begin{tabular}{|c|c|c|c|c|c|}
\hline \multicolumn{6}{|c|}{ Характеристики ліполітичних ферментних препаратів } \\
\hline \multirow{2}{*}{ Ліпаза } & \multirow{2}{*}{ Продуцент } & \multicolumn{2}{|c|}{ Оптимальні умови } & \multirow{2}{*}{ Активність ферменту } & \multirow{2}{*}{ Походження } \\
\hline & & $\mathrm{pH}$ & $\mathrm{t},{ }^{\circ} \mathrm{C}$ & & \\
\hline Lipase MM & Mucor miehei & $6,5-7,5$ & 40 & 4,000 од/мГ & Sigma-aldrich \\
\hline Ліпаза RJ & $\begin{array}{l}\text { Rhizopus } \\
\text { japonicus }\end{array}$ & $4-8$ & $25-45$ & $\begin{array}{c}50,000 \text { од/г до } \\
5058593,8 \text { од/Г }\end{array}$ & Ладижин ENZIM \\
\hline Lipase RO & Rhizopus oryzae & $2,5-8$ & $15-65$ & 1,000 од/г до 150,000 од/г & BIO-CAT \\
\hline Lipase AN & $\begin{array}{c}\text { Aspergillus } \\
\text { niger }\end{array}$ & $7,0-11$ & $20-60$ & 1,000 од/г до 15,000 од/г & BIO-CAT \\
\hline Lipase G AO & $\begin{array}{l}\text { Aspergillus } \\
\text { oryzae }\end{array}$ & 3-9,5 & $20-65$ & 1,000 од/г & BIO-CAT \\
\hline Yeast Lipase & $\begin{array}{c}\text { Candida } \\
\text { cylindracea } \\
\text { (rugosa) }\end{array}$ & $5-10$ & $40-50$ & 1,000 од/г до 200,000 од/г & BIO-CAT \\
\hline Lipase A & E.Coli & $5-10$ & $40-50$ & 3,000 од/г & $\frac{\text { https://www.mybiosour }}{\text { ce.com/ }}$ \\
\hline
\end{tabular}

Для надання характеристики ферменту в якості субстрату використовувався саломас, який є основною складовою відходів його виробництва.

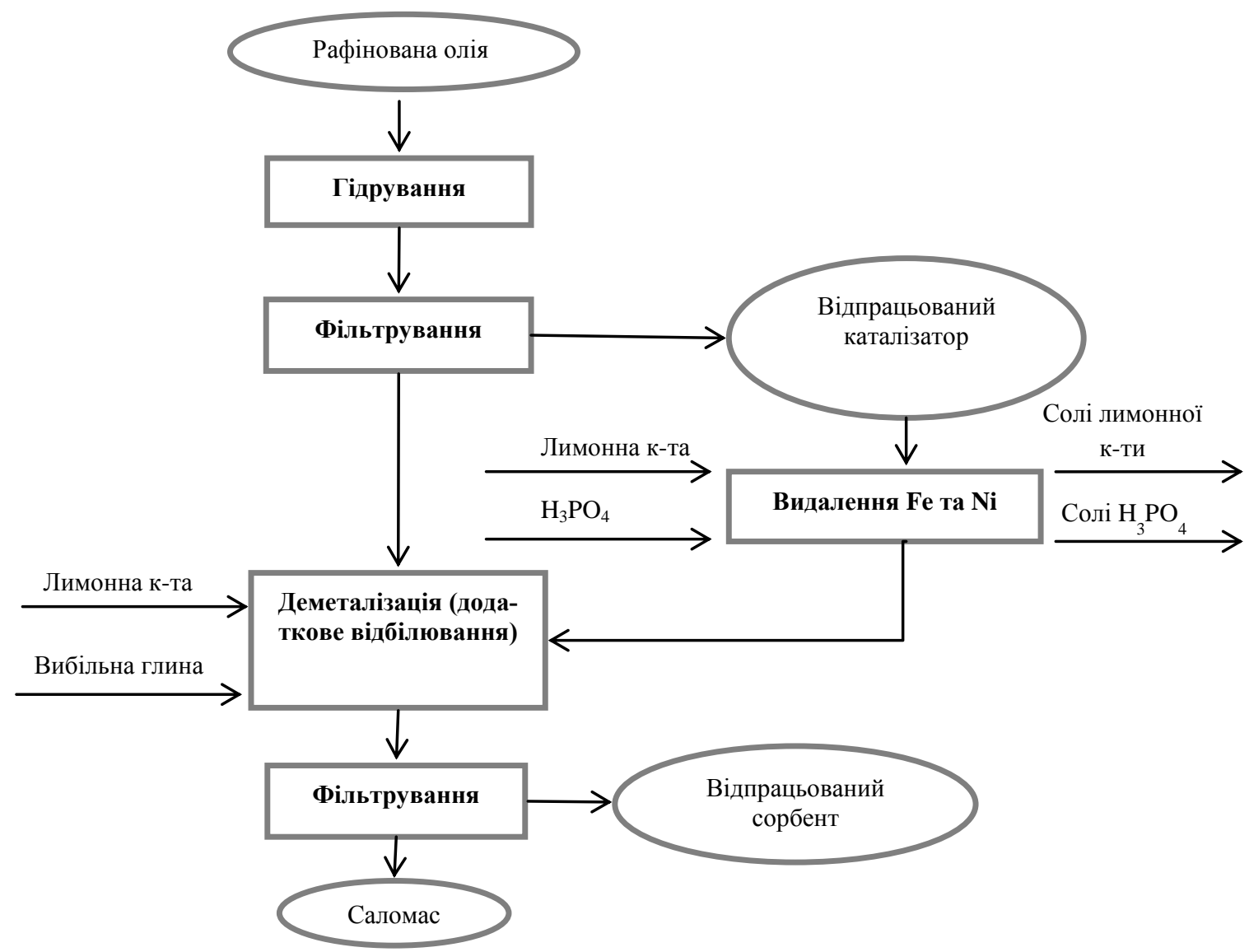

Рис. 2 - Технологічна схема одержання саломасу

Ліполітичну активність визначали титрометричним методом Ota i Yamada [10], який грунтується на розрахунку кількості жирних кислот, що утворилися при гідролізі субстрата. Як субстрат використовували 40 \% емульсію саломасу, що стабілізована полівініловим спиртом. За одиницю активності приймали таку кількість ферменту, яка вивільняє 1 мкмоль кислоти з $40 \%$ суспензії саломасу при $37{ }^{\circ} \mathrm{C}$ за 1 год. У пробірку, що містить $8 \ldots 15$ мг зразка, додавали $1 \mathrm{~cm}^{3}$ води, $0,1 \mathrm{~cm}^{3} 0,1 \%$ розчину ліпази, $0,8 \mathrm{~cm}^{3}$ фосфатного буфеpa (pH середовища відповідав рН-оптимуму ліпази) і термостатували 5 хв при $37^{\circ} \mathrm{C}$. Потім додавали 1,0 см ${ }^{3}$ 40 \% суспензії саломасу з полівініловим спиртом, термостатовану за тих же умов. Через 1 год інкубації реакцію переривали додаванням $5 \mathrm{~cm}^{3} 96 \%$ етанолу. У контрольній пробі емульсію саломасу додавали після внесення етанолу. У контрольну і дослідну проби вносили по три краплі розчину фенолфталеїну і титрували 
розчином гідроксиду натрію концентрацією 0,05 моль/дм ${ }^{3}$ до світло-рожевого забарвлення. Рівень активності ліпази оцінювали в умовних одиницях за різницею в кількості лугу, що пішов на титрування дослідної і контрольної проб при гідролізі 40 \% емульсії саломасу.

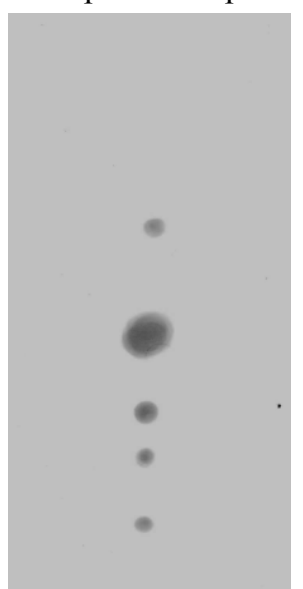

Рис. 3

Тонкошарова хроматограма гідролізату

Активність ліпази розраховували за формулою:

$$
\text { ЛА }=\frac{\left(A-A_{1}\right)}{B} * 100, \text { ЛО/Г }
$$

де А - кількість 0.05 M NAOH, що пішов на титрування дослідного зразка, $\mathrm{cm}^{3}$;

$\mathrm{A}_{1}$ - кількість $0.05 \mathrm{M} \mathrm{NAOH,} \mathrm{що} \mathrm{пішла} \mathrm{на} \mathrm{титрування} \mathrm{контрольного} \mathrm{зразка,} \mathrm{cm}^{3}$;

В - кількість ферменту в реакційній суміші, міліграм;

100 - коефіцієнт для перерахунку в мікромоль;

ЛА - ліполітична активність.

Ліпідний склад гідролізатів визначали методом тонкошарової хроматографії на пластинках марки «Sorbfill-ПТСХ-АФ-А» (100x100 мм) з системою розчинників петролейний ефір (40-70):диетиловий ефір:оцтова кислота=80:20:1[11]. Проявку одержаних хроматограм здійснювали в насиченому йодом ексикаторі (рис.3).

Термостабільність ліпази досліджували таким чином, що рівні за активністю проби ферменту в відповідному буферному розчині, який відповідає $\mathrm{pH}$-оптимуму, інкубували при 20, 37, 45 і $60{ }^{\circ} \mathrm{C}$ протягом 0...360 хв, потім доводили температуру до $37^{\circ} \mathrm{C}$ і визначали активність ферменту.

Результати досліджень та їх обговорення. Вибір ліпаз, які досліджували, грунтувався на тому, що, як відомо, активними продуцентами ліпаз є бактерії родів Pseudomonas, Bacillus, актиноміцети Streptomyces, Thermoactinomyces, дріжджі Candida (Yarrowia), міцелярні гриби Rhizopus, Aspergillus, Geotrichum [12]. Із результатів проведених досліджень, представлених в табл. 2, видно, що найбільшу активність відносно оливкової олії проявляє ліпаза Rhizopus oryzae. Найбільшою активністю відносно саломасу відрізняється ліпаза Rhizopus japonicus, яку в подальшому використовували для ферментативного гідролізу відходів олійно-жирової галузі. Як відомо, активність ферменту залежить від субстрату та його характеристик (жирнокислотний склад та ін.), тобто є субстратспецифічною, чим можна пояснити різницю в активностях досліджуваних ліпаз відносно різних субстратів.

Таблиия 2

Характеристика ферментативного гідролізу субстратів

\begin{tabular}{|c|c|c|}
\hline Ліпази & Активність відносно оливкової олії, од/г & Активність відносно саломасу, од/г \\
\hline Liраse MM & 1532 & 408 \\
\hline Ліпаза RJ & 1356 & 457 \\
\hline Lipase RO & 1752 & 353 \\
\hline Lipase AN & 1311 & 205 \\
\hline Lipase G AO & 1450 & 347 \\
\hline Yeast Lipase & 1715 & 435 \\
\hline Lipase A & 1553 & 226 \\
\hline
\end{tabular}

Динаміка гідролізу саломасу досліджувалась в умовах зворотної емульсії, тобто при низькому вмісті води в реакційному середовищі за співвідношення жир:вода=4:1. Процес проводився в стаціонарних умовах протягом 120 год. Встановлено (табл. 3), що вміст вільних жирних кислот в гідролізаті досягав рівня насичення (майже максимального значення) вже через 72 год гідролізу, а концентрація тригліцеридів впродовж цього часу гідролізу знижувалась до мінімального значення.

Таблиия 3

Динаміка зміни ліпідного складу саломасу при ферментативному гідролізі

\begin{tabular}{|c|c|c|c|c|}
\hline \multirow{2}{*}{$\begin{array}{c}\text { Тривалість } \\
\text { гідролізу, год. }\end{array}$} & \multicolumn{3}{|c|}{ Вміст ліпідів, \% } \\
\hline 0 & Моногліцериди & Дигліцериди & Тригліцериди & Жирні кислоти \\
\hline 24 & 0 & 9,5 & 88,1 & 0 \\
\hline 48 & 3,3 & 15,1 & 53,4 & 25,7 \\
\hline 72 & 4,2 & 17,5 & 20,3 & 62,5 \\
\hline 96 & 3,4 & 13,8 & 13,5 & 62,1 \\
\hline 120 & 3,2 & 11,9 & 11,2 & 64,5 \\
\hline
\end{tabular}

3 метою оптимізації умов ферментолізу саломаса ліпазою проведено дослідження термостабільності ліпази. 
Як видно з наведених результатів дослідження (рис. 4), при $100{ }^{\circ} \mathrm{C}$ ліполітична активність нативної ліпази вже через 20 хв. інкубації ії за даних умов знижувалась до $2 \%$ від вихідної.

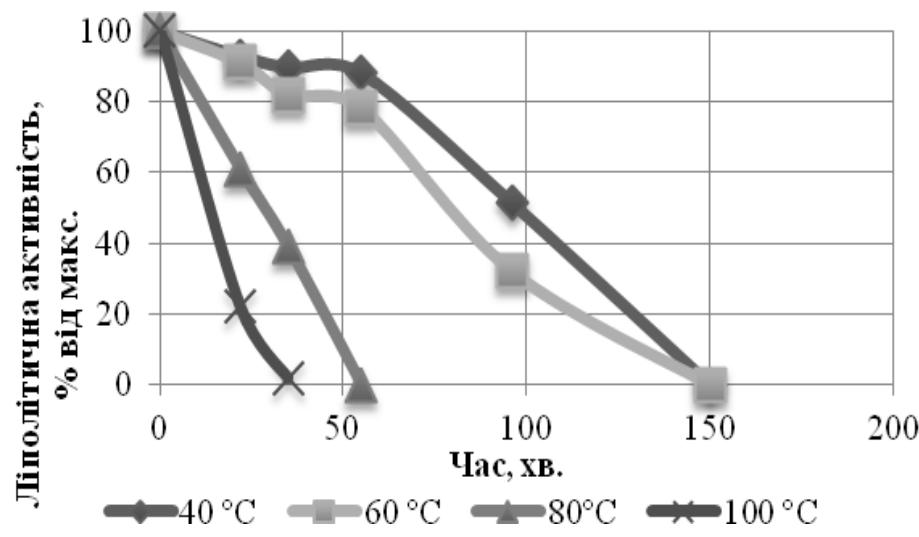

Рис. 4 - Термостабільність ліпази Rhizopus japonicus (pH 7,0)

Найбільша стабільність ліпази спостерігалась при температурі $40{ }^{\circ} \mathrm{C}$ - активність ліпази залишалась стабільною протягом 1,5 год. і повністю втрачалась через 3 години інкубації.

Висновки. Одержані експериментальні результати дослідження свідчать про перспективність ферментативного гідролізу ліпазою Rhizopus japonicus жирової фракції відходів. Встановлено, що ліпаза стабільна в діапазоні $15 \ldots 85{ }^{\circ} \mathrm{C}$ зі збереженням 50 \% активності від максимальної.

При підвищенні температури активність різко знижується. При $100{ }^{\circ} \mathrm{C}$ ліполітична активність нативної ліпази вже через 20 хв. інкубації їі за даних умов знижувалась до 2 \% від вихідної. Встановлено, що ліпаза найбільш стабільна при температурі $40{ }^{\circ} \mathrm{C}$. Таким чином, максимальна активність ферменту спостерігається в області фізіологічних значень температури з ії швидким зниженням при подальшому підвищенні температури, причиною якого є теплова денатурація нативної молекули білка, зміни природи мікрооточення нативного ферменту.

Результати досліджень доцільно використовувати для удосконалення технології переробки відходів олійно-жирової галузі харчової та переробної промисловостей.

References:

1. Ukroliyaprom (2018) Pidsumki roboti haluzi. Asotsiatsiya «Ukroliyaprom»: Retrieved from: http://www.ukroilprom.org.ua/?q=node/205

2. Krusir, H. V., Shevchenko, R. I., Rusieva, Ya. P., Kondratenko, I. P., Krainov, I. P. (2014). Tehnologiyi povodzhennya $\mathrm{z}$ vidhodami harchovih virobnitstv: navch. posib. dlya VNZ. Odesa: Astroprint, 399.

3. Andualema, B, Gessesse, A. (2012). Microbial lipases and their industrial applications: review. Biotechnology, 11, 100-118.

4. Malovanyy, M., Krusir, G., Holodovska, O., Masikevych, A. (2018). Reagent purification of the processing industry enterprises effluents. Food Science and Technology, 12(3), 109-116.

5. Zahorodnii, Ya.O., Tuz, V.O., Sobchenko, H.O., Kostohryz, K. P. (2012). Metody utylizatsii vidbilnykh hlyn. Enerhetyka: ekonomika, tekhnolohii, ekol, 1, 97-102.

6. Romanovska, T.I., Romanovskyi, I.Ia. (2009). Reheneratsiia vidbilnoi hlyny u vyrobnytstvi olii. Nauk. pr. Odeska natsionalna akademiia kharchovykh tekhnolohii, 2(36), 55-57.

7. O.Braien, R. (2007). Zhyrы y masla. Proyzvodstvo, sostav, svoistva, prymenenye. SPb.: Professyia, 752.

8. Cherno, N.K., Krusir, H.V., Kovalenko, O.V. (2009). Biokorektory protsesiv travlennia: monohrafiia. Odesa, 256.

9. Sagdeeva, O.A., Krusir, G.V., Tsykalo, A.L., Shpyrкo, T.V., Leuenberger, H. (2018). Organic waste composting using mineral additives. Food Science and Technology. 12(1), 45-52.

10. Poly`galina, G.V., Cherednichenko, V.S., Rimarev, L.V. (2003). Opredelenie aktivnosti fermentov: Spravochnik. Moskva: DeLi print, 375.

11. Kejts, M. (1975). Tekhnika lipidologii. Vy`delenie, analiz i identifikacziya lipidov. Moskva: Mir, 324.

12. Dykson, M, Uebb, E. (1982). Fermenty. Moskva: Myr, 1120.

Отримано в редакцію 16.04.2019

Прийнято до друку 22.06.2019
Received 16.04.2019

Approved 22.06.2019 